University for Business and Technology in Kosovo

UBT Knowledge Center

Oct 27th, 10:45 AM - 12:15 PM

\title{
An investigation of the effect of bilingual education on language achievement of Kosovar teenagers
}

Marigona Sefedini

University for Business and Technology, marigona.olluri@ubt-uni.net

Follow this and additional works at: https://knowledgecenter.ubt-uni.net/conference

Part of the Education Commons

\section{Recommended Citation}

Sefedini, Marigona, "An investigation of the effect of bilingual education on language achievement of Kosovar teenagers" (2018). UBT International Conference. 117.

https://knowledgecenter.ubt-uni.net/conference/2018/all-events/117

This Event is brought to you for free and open access by the Publication and Journals at UBT Knowledge Center. It has been accepted for inclusion in UBT International Conference by an authorized administrator of UBT Knowledge Center. For more information, please contact knowledge.center@ubt-uni.net. 


\title{
An Investigation of the Effect of Bilingual Education on Language Achievement of Kosovar Teenagers
}

\author{
Marigona Sefedini \\ UBT - Higher Education Institution Str. Lagjia Kalabria p.n., 10000 Prishtinë, \\ Kosovo \\ marigona.olluri@ubt-uni.net
}

\begin{abstract}
The present study investigated the effect of bilingual education on language achievement of Kosovar teenagers. It used bilingual education as an important factor on language achievement, its effect on a third language, and also its impact on the cognitive development. To have a clearer image of the issue, the topic was researched through 40 bilingual learners and 40 monolingual learners. The bilinguals were students who were part of a private secondary school operating a bilingual program, which means every subject of the program was taught in two languages, English and Albanian. Whereas, the monolinguals were students of a public secondary school who were taught only in Albanian. Both groups of the students were examined equally with similar tasks involving a reading comprehension, translation text, dictation and writing. As the purpose of the study was to find the impact of bilingual education on language achievement, the bilingual students showed better results on executive control, communication, creativity, awareness, learning strategy, time-management and showed more positivity and selfconfidence.
\end{abstract}

Key words: bilingual education, language achievement, Kosovo, monolinguals 


\section{Introduction}

The ability to express one's self with confidence and switch easily in two languages is known as bilingualism (Hakuta \& Garcia, 1989). The first language may be the language of home or known as the native language, and the other, of business or of school, for which the former language is inappropriate. Bilingualism occurs when a child is grown in an environment which demands the use of two languages (ASHA, 2004). Bilingualism means the ability to use at least two languages and be familiar with two cultures at the same time (ASHA, 2004). It is a fluctuating system in children and adults whereby use of and proficiency in two languages may change depending on the opportunities of using the languages and exposure to other users of the languages (Bialystok, 1986). More imprecisely, Hamers and Blanc (2000) state that bilingualism is the psychological state of a person who has access to more than one linguistic code as a mean of social communication: the degree of access is of a number of dimensions which are cognitive, psychological, psycholinguistic, social, sociological, sociocultural and linguistic. Unlike foreign language education, in which students study the target language and culture as a subject, bilingual education usually enforces the study of literacy or content areas (math, science, and social studies) through two different languages, in this case English and Albanian.

In our Kosovar schools we have students who come from foreign homes, where the environment is inferior, the social status of living is different, and the opportunities offered for an educational background are limited. The need to be bilingual is growing day by day, and so bilingualism is being considered as a necessity and a beneficial feature on language and academic achievement and also in communicative competence (Suwanarak, 2013). Private schools in Kosovo are the only institutions that have introduced a bilingual education program. Also, they have proved that their students' performance is higher than those of students in public schools, and the reason seems to be the involvement of two languages within the institution.

\section{Purpose of the study}

The purpose of this study is to investigate the effect of bilingual education on language achievement of Kosovar teenagers. Students are divided into two groups, a part of which are instructed in a bilingual education, and the other who are not involved in any bilingual progress. The two groups are compared on measures of general of language achievement, reading comprehension, translation, dictation and essay. The students of the groups were administred the same assessment instrument, the purpose of which was analysing the differences between bilinguals and monolinguals on misspellings, grammar errors, repetition, learning strategies and expression of thought. 
The bilingual program students, Group A, consists of a total of 40 students, mixed gender. The non-bilingual program students, Group B, consists of 40 students, mixed gender too. Group A are students of a private secondary school "Mehmet Akif College," which offers classes in English and in Albanian. Whereas, the non-bilingual group aree students from the Gymnasium "Ulpiana," a public secondary school that offers classes only in Albanian. The native language of both of the groups is Albanian, but the Group A students use English as a study language for all subjects, and so they develop their knowledge and language skills in two different languages. In other hand, Group B uses English only as an obligatory subject. This comparison of monolinguals and bilinguals will reveal the development of students on language.

\section{Importance of the problem}

The present study is important to educators and the field of bilingual education. In 2003 was the first time when an American School was opened, which operates with a bilingual study-program.. Thus it became possible for students to undergo a totally different beginning. This school provided students subjects in both Albanian and English Language, through which students could be able to think and learn science, art and other subjects in two languages. After 2003, there were a big number of schools which were opened and introduced bilingual education in their study program. Parents were attracted and motivated to bring their children to such institutions, and help them develop their language skills.. This study provided evidence on the influence of bilingual instruction on student language achievement in comparison to those who are not instructed in any bilingual program.

\section{Review of literature}

Bilingualism is a feature of developing two language of instruction with similar knowledge of both languages. It can be observed in every way, and sometimes spontaneously. Sometimes different cases in migration, intermarriages and education opportunities encourage a learner or a simple person to be bilingual. The other cases are when a child has a mother from a different place that uses a different language, and a father with a totally different background. There have been some misunderstandings between researchers on the effects of bilingualism on language achievement. Federman, 2000; Lopez, 2003; Mora, 2000 summarize that bilingual education has a negative effect on labor- 
market outcomes such as educational attainment and earnings. On the other hand, a greater number of researchers say the opposite.

According to their research, bilingualism has positive effects on language achievement. Bialytsok (1986), for example, indicates that teenagers' bilingualism positively affects their ability to fix problems which involve high levels of control of linguistic processing. Moreover, bilingualism provides people with other benefits, specifically on language achievement. People who are able to speak two languages may have more possibilities in education and in employment. Further on, the ability to switch between two languages can easily correspond to arise the number of opportunities in one language or another. Jepsen, 2009; Green, 1998 obtain similar conclusions that learners in a bilingual program can achieve higher in language proficiency.

Further on, the studies convey that another positive effect of bilingualism on language achievement is on L3 proficiency. Robinson, 2002 states that learners who are bilingual have better possibilities to acquire a third language. Languages have similarities between each other. Similarities may occur on word order, word meaning or word structure. For example, if the learner is bilingual in English and Albanian, he can easily remember words that are similar to a foreign language. German and French have quite similar words to English, and so an EFL learner can easily acquire these languages as a third language. Also, the Albanian language has similarities with the Serbian language, so when being bilingual the learner can easily acquire words from Serbian too.

\subsection{Bilingualism effect on cognitive development}

Bilingualism features are of a varying effects. Even though, bilingualism is a process of many advantages to language achievement, there is a possibility to acquire a language in a useless form. When the first language is valued, and when acquisition of a second language does not replace the first language, bilingualism affects positively. Whereas, in an opposite situation would be subtractive bilingualism, and in this case bilinguals can create disadvantages and harm their language development. However, some research studies in the $1970 \mathrm{~s}$ and 1980 s demonstrated that bilingualism positively influences the child's cognitive and social development (Ben-Zeev, 1977; Cummins, 1976). These studies indicate that bilinguals can be more capable to connect words and develop their metalinguistic skills. Many studies have also found that bilingualism has a positive effect on foreign language achievement (Cummins, 1979; Klein, 1995; Sanz, 2000). Eisenstein (1980) for instance, found that childhood bilingualism has a positive effect on adult capacity for learning a foreign language. That means that individuals who learned a second language during childhood would have a greater achievement in learning foreign languages as adults. 


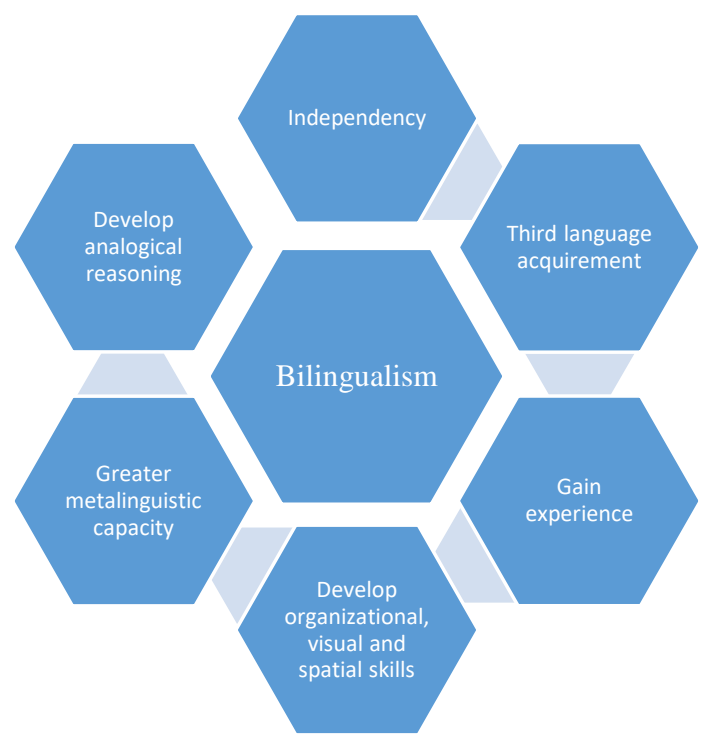

Fig. 1. Benefits of Bilingual Education on Cognitive Skills

\section{Hypothesis}

The major hypothesis investigated in this study were:

1. Bilingual program students will attain higher scores in reading comprehension in English than non-bilingual program students.

2. Bilingual program students will attain higher scores in vocabulary than nonbilingual program students.

3. Bilingual program students will show better results on writing and be more careful in the use of grammar rules.

4. Bilingual program students will be more confident during the sessions than nonbilingual program students.

5. Bilingual program students will finish the tests faster than non-bilingual program students.

In the case of showing higher reading comprehension scores and vocabulary, will indicate greater competency in the variable measures. The higher scores in writing will show more positive attitude of students. And the faster the students are will show confidence and courage to present a finished task. 
Some of the most important issues that come after the linguistic diversity are the cognitive and educational outcomes for bilingual children. A necessary step is to reveal whether language acquisition advances at the same rate and in the same manner for children who are learning two languages simultaneously, or are learning a second language after having begun to be proficient in one.

Will they attain higher scores in English than non-bilingual program students? Will they attain higher grade point average than the others? Will they attain a more positive selfesteem than non-bilingual students? Will bilingual education influence on students' language skills and how will students benefit from it? In what areas will the bilingual education be more advantageous?

There are many questions which need to be answered in studies concerning the influence of bilingual education on the achievement of teenagers* Will students achieve better reading comprehension as a result of participation in a formal bilingual education program? Will a learner's overall academic achievement be higher because of being instructed in a bilingual education program? Will participation in a bilingual education program result in a higher self-esteem?

\section{Methodology}

The present study follows a cross-sectional design with thwo learner cohorts for comparison purposes. First, the monolingual cohort, which includes $40 \mathrm{EFL}$ teenagers who are balanced bilingual in Albanian and English. Second, 40 students who are monolingual speakers of L1 Albanian. In the initial stage, an OQPT is administred to both groups of the students to see if the students can be entered the next tests. The groups of the students are divided according to the institution they come, private or public.

Table 1. The characteristics and the results of the students on OQPT test

Scores of OQPT Test

\begin{tabular}{lllll}
\hline & N & Age & Grade & $\begin{array}{l}\text { Proficiency } \\
\text { language level } \\
\text { (EFL) (OPT Test } \\
\text { scores) }\end{array}$ \\
\hline Monolingual & 40 & $16-18$ & $10-12$ & B1 (30.76) \\
\hline Bilingual & 40 & $16-18$ & $10-12$ & B1 (33.50) \\
\hline
\end{tabular}


In the next phase, the students were given a reading passage. Both groups of students had to deal with the same text and do after-reading activities, such as summary, discussion, and answer open-ended questions. The aim of the second assessment was to identify the reading, understanding and speaking abilities of the learners. After the reading comprehesion, the students were given a translation text. The purpose of this was to find students' skills on literacy and their abilities on transmitting meaning from one language to another. After reading comprehension and translation, the third session included dictation and writing. The intention of using a dictation test was to discover the fluency of students and their capability of writing words correctly. Whereas, the writing task comprised of an essay, which helped to reveal the vocabulary size of the two groups and analyse their use of grammar rules.

\section{Results}

In this study data were analysed from two different group of students: bilinguals and monolinguals. The two groups were equated on language development and they were measured for reading comprehension, translation skills, writing and also for dictation. The main purpose of the study was to find if bilingual education impacts on language achievement and the best method was to investigate two different types of students. The students selected were 40 from a school that uses a study-program in Albanian and English , and the other group were students who were part of a school that uses only Albanian as a study-language. The data were analysed using a T-test for Unequal Variances in Excel.

Table 2. The results of the Reading Comprehension from Bilingual and Monolingual Students

\begin{tabular}{|l|r|r|}
\hline & Bilinguals & Monolinguals \\
\hline Mean & 23.64102564 & 19.53846154 \\
\hline Variance & 18.81511471 & 12.67611336 \\
\hline Observations & 39 & 39 \\
\hline Hypothesized Mean Difference & 0 & 73 \\
\hline df & 4.565547657 & \\
\hline t Stat & $9.87434 \mathrm{E}-06$ & \\
\hline$P(T<=t)$ one-tail & 1.665996224 & \\
\hline t Critical one-tail & $1.97487 \mathrm{E}-05$ & \\
\hline$P(T<=t)$ two-tail & 1.992997126 & \\
\hline t Critical two-tail & & \\
\hline
\end{tabular}

The maximum points of the Reading Comprehension were 30, and it seems that most of the bilinguals showed higher results than monolinguals. Among 40 bilinguals, 2 of 
them were less active and achieved only 12 and 15 scores in the reading comprehension. Whereas, in the monolingual group, more than 5 students achieved 10 to 16 scores. However, a big number of monolinguals showed great results, scoring mostly 24-28 points.

Table 3. The use of literal translation between the two groups of students

\begin{tabular}{|l|r|r|}
\hline & Bilinguals & Monolinguals \\
\hline Mean & 2.128205128 & 4.897435897 \\
\hline Variance & 3.956815115 & 2.726045884 \\
\hline Observations & 39 & 39 \\
\hline Hypothesized Mean Difference & 0 & \\
\hline df & 74 & \\
\hline t Stat & -6.689755387 & \\
\hline$P(T<=t)$ one-tail & $1.85136 \mathrm{E}-09$ & \\
\hline t Critical one-tail & 1.665706893 & \\
\hline$P(T<=t)$ two-tail & $3.70272 \mathrm{E}-09$ & \\
\hline t Critical two-tail & 1.992543495 & \\
\hline
\end{tabular}

Bilinguals seem to have a large vocabulary of words. They appear to be more creative in translating texts and most importantly they are good at neglecting repetition of words. From the results on how many literal sentences students have been used, a few students of the Group A show that they have used 2-4 literal sentences maximum, whereas students from the Group B (monolinguals) are considered to have more sentences translated literally or word-by-word.

The third session included dictation and writing. From this session, students' data were analysed for misspelling and missed words. When analyzing the data, it could be seen that bilinguals are very experienced and strategic. The bigger part of the bilinguals were determined and confident for the words they had written. On the other hand, monolinguals seemed to be a bit confused and undecided and maybe for this reason sometimes they missed words and did misspellings. The next instrument of the third stage was an essay, whose purpose was to analyse and find out the differences between bilinguals and monolinguals in writing. The students were finally administred an essay topic, through which their data were analysed for grammar errors and repetition. The errors that occured mostly at the monolingual group of students were wrong written words, such as "advise" instead of "advice" or "adverse" instead "averse". Next, there were some essays where the punctuation rules were neglected, in comparison to bilinguals. Another mistake was the usage of run-on-sentences. A number of students were not careful enough to separate clauses in a sentence. 
For example:

I like the city but I can't stand the pollution. Instead of: I like the city, but I can't stand the pollution.

\section{Discussion}

Eventhough there were dissagreements and missconceptions about bilingualism effect, from advantages to disadvantages, some of which are now questions, this study has shown more positive effects of bilingualism on language achievement. That means, bilingual learners have more possibilities to acquire a foreign language rather than monolinguals. The results showed slight benefits for bilinguals versus monolingual learners what means that bilinguals are slightly better than monolingual counterparts. The comparisons of EFL bilingual and monolingual learners are not frequent: This is the main asset of the present study.

*Bilinguals have a better working memory and executive control.

*Bilinguals have higher degrees of communicative sensitivity, creativity and metalinguistic awareness.

*They are more experienced and more strategic learners (better users of learning strategy.) *Bilinguals are faster learners

*Bilinguals have more positive attitudes toward foreign language learning.

\section{Conclusion}

The research topic |"An Investigation of the Effect of Bilingual Education on Language Achievement of Kosovar Teenagers" resulted from my interest in exploring how bilingualism may affect on language achievement of two different groups of students. I decided to make a comparison between two groups of EFL learners, one whose members are bilingual in English and Albanian and the other who are monolingual in Albanian. The topic includes a method to check the achievement on language by the involvement of bilingual education, through vocabulary responses and reading passages. After finding the homogeneity of students, another task is given to finally reveal the comparison between the groups. 
It seems that the bilingual education has positive effects and is beneficial in multiple ways on language development. During the sessions divided for the two groups of students, the bilinguals seemed to be more communicative and self-confident. Bilinguals were free of emotions and opened to any question or misunderstanding, while monolinguals were lessconfident. Moreover, bilingualism impacts also on awareness and creativity. The formation of responses in the test, revealed and also conviced me that bilinguals are more informed and also more creative in giving answers. Another benefit was the strategy bilinguals use during a task given and the time-management. It seems that bilinguals are really fast and use the time properly for each question. The study of the effect of bilingualism on language achievement to Kosovar EFL Pre-Intermediate learners merits further attention, since it reflects on ongoing growing reality and it opens new avenues for further research.

\section{References}

1. American Speech-Language-Hearing Association. (2004). Knowledge and Skills Needed by Speech-Language Pathologists and Audiologists to Provide Culturally and Linguistically Appropriate Services [Knowledge and Skills]. Retrieved from: www.asha.org/policy.

2. Bialystok, E. (1986). Children's concept of word. Journal of Psycholinguistic Research. 15(1), 13-32.

3. Ben-Zeev, S. (1977). The Influence of Bilingualism on Cognitive Strategy and Cognitive Development. Society for Research in Child Development. 48 (3), pp. 1009-1018. Retrieved from: https://www.jstor.org/stable/1128353

4. Cummins, J. (1978). Bilingualism and the development of metalinguistic awareness. Journal of Crosscultural Psychology. 9(2), 131-149.

5. Federman, M. (2000). Bilingual Education, College Major Choice, and College Remediation. Ph.D. Dissertation, Harvard University

6. Green, J. (1998). A Meta-Analysis of the Effectiveness of Bilingual Education. The Thomas Rivera Policy Institute

7. Hakuta, K., \& Garcia, E. E. (1989). Bilingualism and education. American Psychologist, 44(2), 374-379.

8. Hamers, J.F., \& Blanc, H.A (2000). Bilinguality and Bilingualism. Cambridge University Press, Cambridge CB2 1RP, UK.

9. Jepsen, Ch. (January 2009). Bilingual Education and English Proficiency.

10. Klein, E. (1995). Second versus Third Language Acquisition: Is There a Difference? A Journal of Research in Language Studies. 45 (3). pp. 419-466.

11. Lopez, M. H. (2003). Do English Language Assistance Programs Affect Educational Attainment and Labor Market Outcomes? : Evidence from the National Education Longitudinal Study of 1988 and High School and Beyond. Unpublished manuscript, Maryland University.

12. Mora, M. T. (2000). English-language assistance programs, English skill acquisition, and the academic progress of high school language minority students. Policy Studies Journal, 28(4), 761-783.

13. Sanz, C. (2000).Bilingual education enhances third language acquisition: Evidence from Catalonia. Applied Psycholinguistics, 21, 23- 4. 